\title{
Luc Gene
}

National Cancer Institute

\section{Source}

National Cancer Institute. Luc Gene. NCI Thesaurus. Code C19243.

Luc Genes encode Luciferase, flavoprotein enzymes in certain marine crustaceans, fish, bacteria, and insects that catalyze bioluminescent oxidization of Luciferins to an electronically excited compound that emits energy in the form of light. The firefly enzyme is a valuable reagent for measurement of ATP concentration. $(\mathrm{NCl})$ 